\title{
The impact of bark beetle infestations on monoterpene emissions and secondary organic aerosol formation in western North America
}

\author{
A. R. Berg ${ }^{1}$, C. L. Heald ${ }^{2}$, K. E. Huff Hartz ${ }^{3}$, A. G. Hallar ${ }^{4}$, A. J. H. Meddens ${ }^{5}$, J. A. Hicke ${ }^{5}$, J.-F. Lamarque ${ }^{6}$, and \\ S. Tilmes ${ }^{6}$ \\ ${ }^{1}$ Department of Atmospheric Science, Colorado State University, Fort Collins, Colorado, USA \\ ${ }^{2}$ Department of Civil and Environmental Engineering \& Department of Earth, Atmospheric, and Planetary Sciences, \\ Massachusetts Institute of Technology, Cambridge, Massachusetts, USA \\ ${ }^{3}$ Department of Chemistry and Biochemistry, Southern Illinois University Carbondale, Carbondale, Illinois, USA \\ ${ }^{4}$ Storm Peak Laboratory, Desert Research Institute, Steamboat Springs, Colorado, USA \\ ${ }^{5}$ Department of Geography, University of Idaho, Moscow, Idaho, USA \\ ${ }^{6}$ National Center for Atmospheric Research, Boulder, Colorado, USA
}

Correspondence to: C. L. Heald (heald@ mit.edu)

Received: 30 October 2012 - Published in Atmos. Chem. Phys. Discuss.: 20 November 2012

Revised: 3 March 2013 - Accepted: 4 March 2013 - Published: 15 March 2013

\begin{abstract}
Over the last decade, extensive beetle outbreaks in western North America have destroyed over $100000 \mathrm{~km}^{2}$ of forest throughout British Columbia and the western United States. Beetle infestations impact monoterpene emissions through both decreased emissions as trees are killed (mortality effect) and increased emissions in trees under attack (attack effect). We use $14 \mathrm{yr}$ of beetle-induced tree mortality data together with beetle-induced monoterpene emission data in the National Center for Atmospheric Research (NCAR) Community Earth System Model (CESM) to investigate the impact of beetle-induced tree mortality and attack on monoterpene emissions and secondary organic aerosol (SOA) formation in western North America.

Regionally, beetle infestations may have a significant impact on monoterpene emissions and SOA concentrations, with up to a 4-fold increase in monoterpene emissions and up to a $40 \%$ increase in SOA concentrations in some years (in a scenario where the attack effect is based on observed lodgepole pine response). Responses to beetle attack depend on the extent of previous mortality and the number of trees under attack in a given year, which can vary greatly over space and time. Simulated enhancements peak in 2004 (British Columbia) and 2008 (US). Responses to beetle attack are shown to be substantially larger (up to a 3-fold localized increase in summertime SOA concentrations) in a scenario based on bark-beetle attack in spruce trees. Placed
\end{abstract}

in the context of observations from the IMPROVE network, the changes in SOA concentrations due to beetle attack are in most cases small compared to the large annual and interannual variability in total organic aerosol which is driven by wildfire activity in western North America. This indicates that most beetle-induced SOA changes are not likely detectable in current observation networks; however, these changes may impede efforts to achieve natural visibility conditions in the national parks and wilderness areas of the western United States.

\section{Introduction}

In the last decade, western North America has experienced the largest bark beetle outbreaks in recorded history (Taylor et al., 2006). The main beetle impacting the region is the mountain pine beetle (MPB), with nearly $74 \%$ of needleleaf tree mortality associated with this beetle (Man, 2012). The MPB is native to western North America and can kill large numbers of pine trees annually, attacking mainly lodgepole pine and ponderosa pine. Mountain pine beetles bore under the bark of host trees, eventually killing the tree as the beetles consume the phloem and introduce a virulent fungus. In the United States, MPB infestation peaked in 2009 with 0.9 million hectares of killed trees (Meddens et al., 2012). In British 
Columbia, the area of infestation peaked in 2005-2007 with almost 1 million hectares of trees killed annually during these years (Meddens et al., 2012). Although the area infested in both British Columbia and the western United States has decreased recently, beetles continue to expand into new areas (Westfall and Ebata, 2011).

Geographical expansion of the MPB has been limited in the past by climate (Carroll et al., 2003). Several studies have attempted to model the future impacts and timing of the expansion of the MPB based on climate change effects and changing pine stand characteristics (e.g. Hicke et al., 2006; Bentz et al., 2010). These studies agree that warming over the next century will allow MPB outbreaks to occur at progressively higher elevations, possibly supporting an on going MPB outbreak for decades. Climate change may also lead to drought and elevated surface ozone concentrations, both of which increase tree stress making them more susceptible to beetle attack (e.g. Raffa et al., 2008; Jones et al., 2004).

Insect damage may impact forests by shifting them from a carbon sink to a carbon source (e.g. Kurz et al., 2008; Hicke et al., 2012a). Bark beetle infestation alters carbon stocks differently than stand-replacement wildfires or clearcut harvesting because smaller diameter trees and non-host trees typically survive a beetle infestation, leading to a different pattern of mortality (Pfeifer et al., 2010). Beetle infestation can impact forest fire susceptibility and activity by increasing the risk of active crown fire in dry beetle-killed forest and decreasing the risk of active crown fire when needles fall (e.g. Simard et al., 2011; Hicke et al., 2012b). Insect attack can also alter surface-atmosphere exchanges of heat, water, and momentum through land surface modification (e.g. Wiedinmyer et al., 2012; Edburg et al., 2012). Hais and Kucera (2008) estimate a $3.5 \mathrm{~K}$ increase in temperature in a spruce forest after beetle attack. In addition, snowpack in a beetle-killed forest can also be prolonged (Boon, 2007; Perrot et al., 2012).

Bark beetle attack can also prompt elevated monoterpene emissions in trees (e.g. Amin et al., 2012), with potential implications for local air quality. The emissions enhancement is likely a defense mechanism of the tree that consists of increasing resin flow to remove beetles, increasing emissions of compounds that are toxic to the beetles, and attracting predators of the beetles (Pare and Tumlinson, 1999). A few studies have examined and quantified monoterpene concentration and emission changes under beetle attack for specific tree species including lodgepole pine, ponderosa pine, and Engelmann spruce. These studies include both beetle infestation studies and fungal inoculation studies and have found significant increases in monoterpenes due to beetle attack (e.g. Gara et al., 1993; Litvak and Monson, 1998; Jost et al., 2008; Amin et al., 2012; Prieme et al., 2000; Blande et al., 2007; Brilli et al., 2009). Insect herbivory can induce both substantial increases in total monoterpene emissions from vegetation and changes in the emission profile, with implications for atmospheric composition. While not the focus of this study, sesquiterpene emission rates are also elevated in conifers experiencing bark beetle attack (Heijari et al., 2011).

Monoterpenes are oxidized in the atmosphere to form lower volatility products which may partition into the particle phase, forming secondary organic aerosol (SOA). These oxidation processes can also lead to ozone formation with important implications for global atmospheric composition. SOA formed from monoterpenes and other compounds can impact earth's radiative balance through the direct effect of scattering incoming solar radiation and the indirect effect on cloud albedo and lifetime (Lohmann and Feichter, 2005). Atmospheric visibility may also be degraded by SOA formation in forests. National parks and other protected wilderness areas in the western US are currently impacted by beetle infestation and these are areas where the Environmental Protection Agency (EPA) has mandated an improvement in visibility under the Regional Haze Rule (US EPA, 1999).

Despite growing evidence that bark beetle attack can enhance monoterpene emissions from vegetation, in addition to the role that these beetles play in changing land cover and density, no study has quantified the impact of these changes on regional air quality and visibility. In this work, we use beetle-caused tree mortality data from 1997-2010 and beetle-induced monoterpene data from the recent literature in the National Center for Atmospheric Research (NCAR) Community Earth System Model (CESM) to study the impact of beetle infestation on monoterpene emissions and SOA formation in western North America. We compare two scenarios based on beetle-induced monoterpene data from lodgepole pine and Engelmann spruce and focus on the spatial and temporal evolution of monoterpene emissions and the SOA formed due to cumulative beetle attack and subsequent forest mortality in the model.

\section{Model description}

The NCAR CESM consists of coupled global models for the atmosphere, ocean, land, land ice, and sea ice (Gent et al., 2011). In this work we use v1.1 of the CESM in a configuration where the land and atmosphere are coupled with imposed ocean (sea surface temperature) and sea ice conditions for the present day. The simulations are run at $1.9^{\circ} \times 2.5^{\circ}$ horizontal resolution from 1997 to 2010 (with specified meteorological fields from reanalysis; see below) representing $14 \mathrm{yr}$ of cumulative beetle kill in western North America.

\subsection{Land model, land cover, and beetle-induced tree mortality}

The land model used in this study is version 4 of the Community Land Model (CLM4, Lawrence et al., 2011). CLM4 describes the physical, chemical, and biological processes of terrestrial ecosystems, including the hydrology and carbon cycling of the terrestrial biosphere. Vegetation is specified 


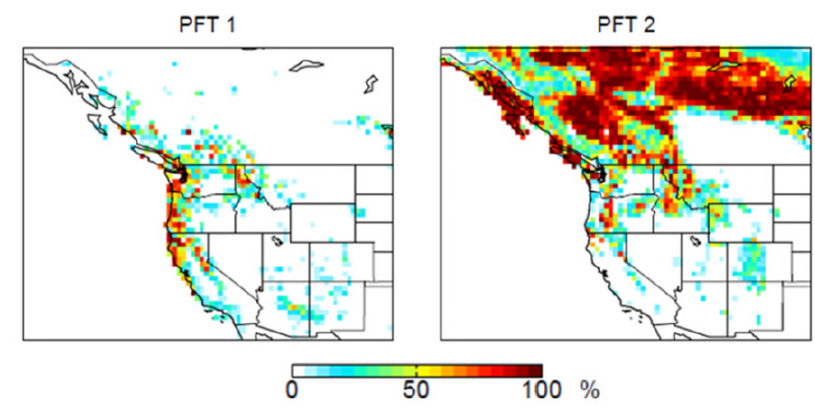

Fig. 1. Percent of total surface area occupied by PFT 1 (needleleaf evergreen temperate tree) and PFT 2 (needleleaf evergreen boreal tree) in western North America.

by 16 plant functional types (PFTs). Leaf area index (LAI) is also specified for each month for each PFT. PFT distributions are based on Moderate Resolution Imaging Spectroradiometer (MODIS) land surface datasets (Lawrence and Chase, 2007) and a cropping dataset (Ramankutty et al., 2008). Figure 1 shows coverage of needleleaf forests (PFT 1 and PFT 2 ), the vegetation types susceptible to beetle attack in western North America.

Beetle-caused tree mortality data are from Meddens et al. (2012). These data were created for the western United States (US) from the US Forest Service Aerial Detection Survey Program (1997-2010) and for British Columbia (BC) from the BC Ministry of Forests Aerial Overview Program (2001-2010). The data are at $1 \times 1 \mathrm{~km}$ grid resolution. Mortality area within each grid cell (crown area of killed trees) was converted from information provided by the US and BC aerial surveys by year and by beetle species. Because the MPB has had such a significant impact in western North America compared to other beetles, the impacts from the MPB are compared to impacts from the other 12 beetle species combined (OB) in this study. Figure 2 shows the spatial and temporal extent of tree mortality in $\mathrm{BC}$ and the western US caused by the MPB and the OB. Bark beetle attack has resulted in extensive damage over the last decade, with total vegetated area decreasing by up to $30 \%$ in some grid cells.

Meddens et al. (2012) indicate that the US aerial survey data underestimates the number of trees killed based on field observations in Idaho, Colorado, and New Mexico. Using remotely sensed imagery of beetle outbreak locations in Idaho, northcentral Colorado, and northern New Mexico, they developed and applied factors to adjust the US beetleinduced tree mortality data to match the image-derived mortality area. This more realistic upper estimate improves the agreement with field observations and the continuity with BC data across the US-Canada border. The adjusted data are used for the US in this study.

Uncertainties in the mortality data include variability in estimates in space and time due to differing abilities and tech-
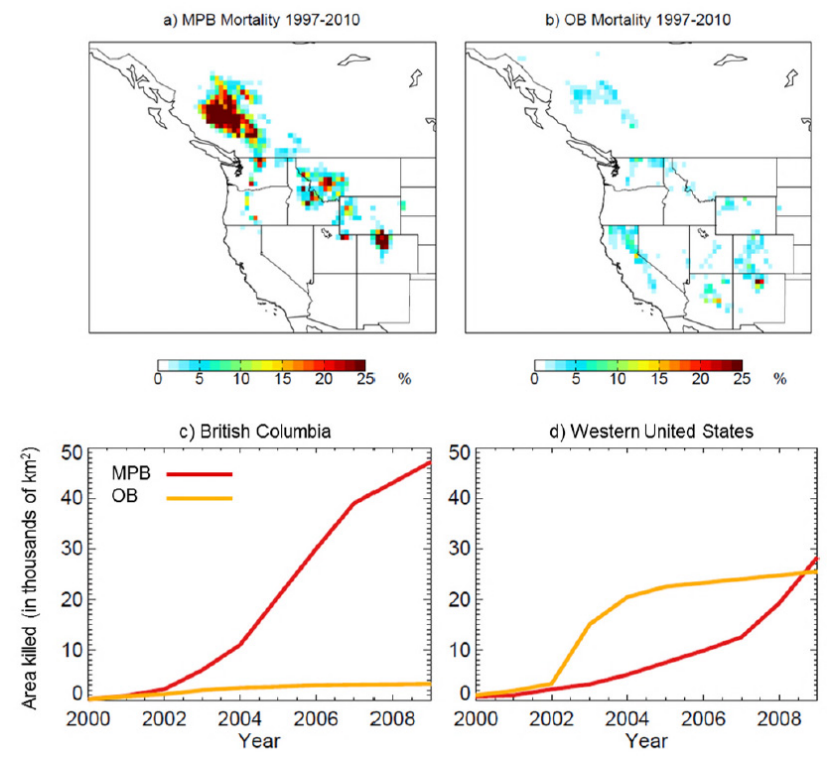

Fig. 2. Cumulative percent of area killed in 2010 in $B C$ and the western US due to (a) mountain pine beetle (MPB) and (b) other beetles (OB) (color bar saturated at $25 \%$ ), and cumulative beetleinduced tree mortality over time in (c) BC and (d) western US caused by the mountain pine beetle and other beetles.

niques of different mappers, the mean tree crown area values used for calculating mortality in a grid cell, incomplete data collection (wilderness or national park areas were not regularly surveyed), and the adjustment factors for the US. The sharp increase in the other beetle-induced tree mortality seen in 2003 (Fig. 2) is due in part to incomplete surveying of a pinyon ips beetle outbreak in the Southwest US in 2002. Surveys were not routinely conducted for pinyon pine forests before 2003 and so pinyon ips mortality added in 2003 includes mortality from the preceding years.

Changes in plant functional type coverage are calculated to correspond with the beetle-caused mortality datasets, at the $1.9^{\circ} \times 2.5^{\circ}$ horizontal resolution used here. Cumulative PFT reductions are calculated for each year from 1997-2010. Because the PFTs do not break into specific tree species and maps of sub-PFT species composition are not available, the mortality data are applied to the two needleleaf PFTs covering western North America (Fig. 1) to simulate beetle attack. Given that the mortality data are provided as a percentage of area, total tree mortality is conserved by this approach. As a result of the PFT reductions, total LAI decreases with bark beetle kill. The original CLM PFT dataset is used as the baseline. In some grid cells mortality area can exceed PFT coverage, because the PFT coverage and mortality data are from two different sources. In these cases, mortality is capped at this maximum PFT coverage. 


\subsection{Monoterpene emissions}

The Model of Emissions of Gases and Aerosols from Nature (MEGAN 2.1) is used in CLM4 to estimate emissions from terrestrial vegetation of up to 150 different biogenic volatile organic compounds (BVOCs), including isoprene, monoterpenes, sesquiterpenes, and other oxygenated volatile organic compounds (VOCs) (Guenther et al., 2012). A VOC flux in units of $\mu \mathrm{mol} \mathrm{m} \mathrm{m}^{-2} \mathrm{~h}^{-1}$ is calculated from a baseline emission that is modulated by an emission activity factor, which accounts for emission responses to meteorological and phenological conditions, including light, temperature, leaf age, and LAI. There is a specific emission factor for each PFT for each compound. In CLM4, the BVOC emissions are calculated interactively at every time step.

Bark beetle infestation has two main effects on VOC emissions from trees. First, the attack effect is the increase in VOC emissions that occurs while a tree is under attack. To simulate the attack effect in the model, scale-up factors for the monoterpene emissions are calculated from field observations (see below) and applied to the fraction of needleleaf evergreen that is under attack in each year. The increase in mortality from the current year to the next year corresponds to trees under attack in the current year. We note that some trees attacked by beetles can survive the attack, and that these trees would not be accounted for here as the mortality dataset only includes trees under attack that subsequently died. Second, the mortality effect is the decrease in VOC emissions that occurs after trees are killed. This simplification assumes that monoterpene emission rates from dead wood and needle litter are effectively zero. This effect is implemented through the reduction in evergreen needleleaf PFT coverage.

To estimate the attack effect on monoterpene emissions we consider two scenarios based on field observations of infested trees. Amin et al. $(2012,2013)$ compared sorbent trap concentrations of monoterpenes emitted from healthy lodgepole pine and Engelmann spruce trees to pine and spruce under attack by bark beetles. In the first scenario, we apply relative increases in the monoterpene compounds 3carene, $\beta$-phellandrene, $\beta$-pinene, and $\mathrm{p}$-cymene calculated from the lodgepole pine data from Amin et al. (2012). In the second scenario, we use relative increases in 3-carene, $\beta$ phellandrene, $\beta$-pinene, $\mathrm{p}$-cymene, $\alpha$-pinene, and sabinene from the Amin et al. (2013) Engelmann spruce data (Table 1). Scale-up factors could not be calculated for compounds not detected in healthy trees. Table 1 also includes the baseline simulated total emission of these monoterpenes for western North America. Overall, the largest relative increase is for $\beta$-phellandrene in the pine study and 3-carene in the spruce study. For each scenario, the factors are applied to PFT 1 and PFT 2 for all locations under bark beetle attack, assuming that all trees would respond the same way to infestation by different bark beetle species. Although numerous studies have demonstrated that the VOC increase occurs in many plant species caused by many insect species (e.g. Blande et
Table 1. Scale-up factors for bark beetle-induced changes in monoterpene emissions calculated from Amin et al. (2012, 2013) lodgepole pine and Engelmann spruce data.

\begin{tabular}{lrrr}
\hline \multirow{2}{*}{ Monoterpene } & \multicolumn{2}{c}{ Scale-up Factor } & $\begin{array}{r}\text { Baseline simulated total emissions } \\
\text { (western North America) }\end{array}$ \\
\cline { 2 - 3 } & Pine & Spruce & $\operatorname{TgC~yr}^{-1}$ \\
\hline$\beta$-pinene & 7.7 & 16 & 0.36 \\
3-carene & 7.3 & 65 & 0.19 \\
$\beta$-phellandrene & 33 & 5.3 & 0.036 \\
P-cymene & 5.4 & 42 & 0.014 \\
$\alpha$-pinene & - & 3.6 & 0.63 \\
Sabinene & - & 18 & 0.099 \\
\hline
\end{tabular}

al., 2007; Brilli et al., 2009; Staudt and Lhoutellier, 2007), differences between the pine and spruce scale-up factors indicate that different tree species may have very different responses to bark beetle attacks. We include these two scenarios here in an effort to characterize this range of responses.

\subsection{Atmospheric model}

The Community Atmosphere Model (CAM4) is a 3-D global atmospheric model. We use specified meteorological fields generated from the GEOS-5 product for 2008 (Rienecker et al., 2008). CAM can be run with an interactive atmospheric chemistry scheme based on the MOZART-4 (Model of Ozone and Related Chemical Tracers) chemical transport model, a configuration known as CAM-Chem. Lamarque et al. (2012) describe the features of the CAM-Chem model, as well as validation against observations. The chemical mechanism used here contains extensive tropospheric chemistry, including $\mathrm{O}_{3}, \mathrm{NO}_{\mathrm{x}}, \mathrm{SO}_{\mathrm{x}}, \mathrm{CO}$, VOC oxidation processes, and a bulk aerosol scheme including sulfate, ammonium nitrate, carbonaceous aerosols, SOA, sea salt, and dust. Major BVOC species or classes are calculated within CLM4 and fed into the chemical mechanism of CAM-Chem (e.g. isoprene, monoterpenes, acetone, etc.). For these bark beetle simulations, the emissions for select speciated monoterpenes (Table 1) are also input from the CLM4.

\subsection{SOA formation}

SOA in these simulations is produced by applying a fixed yield to the first generation oxidation products of the precursors. We consider SOA formed from both ozonolysis and photooxidation reactions (rates from Atkinson, 1997), following primarily bulk yields measured by Lee et al. (2006a, b) (Tables 2 and 3). There is a large range in measured SOA yields for our species of interest; therefore, we choose Lee et al. (2006a, b) for consistency, but note here the uncertainty in these values. Only one study has looked at SOA yields from $\beta$-phellandrene (Surratt et al., 2008) finding that SOA yields from $\beta$-phellandrene may be similar to limonene SOA yields. Therefore, limonene SOA yields are used here 
Table 2. Photooxidation SOA yields from Lee et al. (2006b, or other studies as noted) and reaction rates from Atkinson et al. (1997). Primary oxidant $\mathrm{OH}$.

\begin{tabular}{|c|c|c|}
\hline Monoterpene & $\begin{array}{l}\text { SOA Mass } \\
\text { Yield }(\%)\end{array}$ & $\begin{array}{l}\text { Reaction Rate at } 298 \mathrm{~K} \text { and } \\
1 \mathrm{~atm}\left(\mathrm{~cm}^{3} \text { molecule }{ }^{-1} \mathrm{~s}^{-1}\right)\end{array}$ \\
\hline Limonene $^{\mathrm{a}}$ & 58 & $1.7 \times 10^{-10}$ \\
\hline$\beta$-pinene & 31 & $7.9 \times 10^{-11}$ \\
\hline 3-carene & 38 & $8.8 \times 10^{-11}$ \\
\hline 1-methyl-3-n-propylbenzene ${ }^{b}$ & 5.6 & $1.4 \times 10^{-11}$ \\
\hline$\alpha$-pinene & 32 & $5.4 \times 10^{-11}$ \\
\hline Sabinene $e^{c}$ & 10.2 & $1.2 \times 10^{-10}$ \\
\hline
\end{tabular}

${ }^{\mathrm{a}}$ Used for $\beta$-phellandrene, ${ }^{\mathrm{b}}$ used for p-cymene (Odum et al., 1997), ${ }^{\mathrm{c}}$ Griffin et al. (1999).

Table 3. Dark ozonolysis SOA yields from Lee et al. (2006a, or other studies as noted) and reaction rates from Atkinson et al. (1997). Primary oxidant $\mathrm{O}_{3}$.

\begin{tabular}{|c|c|c|}
\hline Monoterpene & $\begin{array}{l}\text { SOA Mass } \\
\text { Yield }(\%)\end{array}$ & $\begin{array}{l}\text { Reaction Rate at } 298 \mathrm{~K} \text { and } \\
1 \mathrm{~atm}\left(\mathrm{~cm}^{3} \text { molecule }{ }^{-1} \mathrm{~s}^{-1}\right)\end{array}$ \\
\hline$\beta$-pinene & 17 & $1.5 \times 10^{-17}$ \\
\hline 3-carene & 54 & $3.7 \times 10^{-17}$ \\
\hline$\alpha$-pinene & 41 & $8.7 \times 10^{-17}$ \\
\hline Sabinene $^{a}$ & 3.0 & $8.6 \times 10^{-17}$ \\
\hline
\end{tabular}

${ }^{a}$ Griffin et al. (1999)

to approximate SOA yields for $\beta$-phellandrene. To date, SOA formation from p-cymene has not been investigated. Here we use SOA yields from the structurally similar compound 1-methyl-3-n-propylbenzene from Odum et al. (1997) to approximate SOA yields for p-cymene.

The chamber studies of Lee et al. (2006a, b) were conducted at low $\mathrm{HC}: \mathrm{NO}_{\mathrm{x}}$ ratio, considered representative of a ponderosa pine forest. Temperature dependence of the reaction rates are only available for $\alpha$-pinene and $\beta$-pinene, thus the reaction rates are fixed at $298 \mathrm{~K}$; however, given the short lifetimes of these species, differences in oxidation rates at atmospherically relevant temperatures are negligible. We do not include SOA formed from the reaction of monoterpenes with the $\mathrm{NO}_{3}$ radical due to the difficulty in obtaining yields and reaction rates for the specific monoterpenes considered here. Because monoterpene oxidation by the $\mathrm{NO}_{3}$ radical may be an important source of SOA at night (e.g. Winer et al., 1984; Fry et al., 2009, 2011), the SOA concentrations from monoterpenes simulated here may be a lower limit. SOA from isoprene is also neglected here, but given the relatively low coverage of deciduous trees in western North America, the contribution of this source to total organic aerosol in the region is likely low (Heald et al., 2008). Formed SOA is treated as non-volatile, a necessary simplification given the lack of volatility parameter measurements for all of the specific SOA precursors under consideration. a) Baseline 3-carene emissions

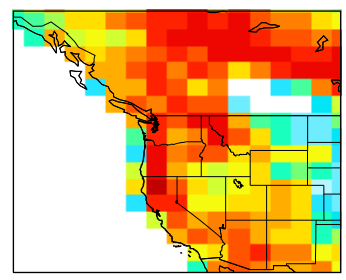

b) Baseline $\beta$-phellandrene emissions

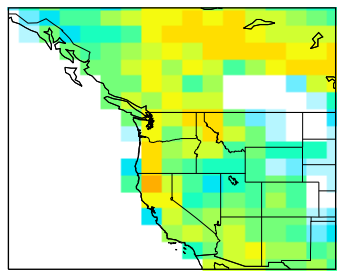

c) Baseline $\alpha$-pinene emissions

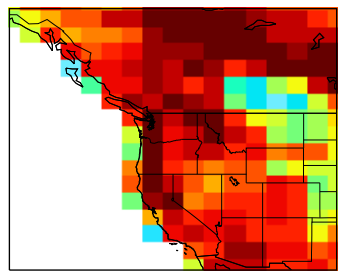

0.001

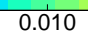

0.100 1.000

$\mu \mathrm{gm}^{-2} \mathrm{~h}^{-1}$

Fig. 3. Baseline summer-mean simulated emissions of monoterpenes potentially influenced by beetles: (a) 3-carene, (b) $\beta$ phellandrene, (c) $\alpha$-pinene, (d) $\beta$-pinene, (e) p-cymene, and (f) sabinene. Color bar is saturated at $1 \mu \mathrm{g} \mathrm{m}^{-2} \mathrm{~h}^{-1}$.

In addition to our specific SOA products, we calculate total SOA formed from all monoterpenes with a yield of $10 \%$ (in order to compare with total organic aerosol observations; see Sect. 3.4). This total $10 \%$ yield may not be consistent with the sum of the individual precursor yields used here, but is in line with the yields estimated from whole plant emission SOA studies (Mentel et al., 2009; Hao et al., 2011).

\section{Results}

\subsection{Impacts on monoterpene emissions in western North America}

Figure 3 shows the simulated summer-mean baseline emissions (i.e. without beetle activity) of the six monoterpenes impacted by bark beetle in this study (totals in Table 1). These emissions peak in the summertime, therefore we focus on that season in our study. Emissions of $\beta$-pinene and 3-carene are the largest, whereas emissions of $\beta$ phellandrene and p-cymene are much smaller. Emissions of 
these monoterpenes are large in the western US, particularly in Washington, Oregon, and Northern California, due to the extensive coverage of needleleaf trees in this region (Fig. 1).

We first show the simulated impact of bark beetle kill on monoterpene emissions and SOA formation based on the observed enhancements in lodgepole pine emissions (Amin et al., 2012; Table 1) (results using spruce scenario are discussed below in Sect. 3.3). Lodgepole pine is the main species under attack by mountain pine beetles (Logan and Powell, 2001; Meddens et al., 2012). The impact of beetle attack on $\beta$-phellandrene emissions is shown as a specific example. This monoterpene has the largest scale up factor for the pine scenario. Figure 4 shows maps of simulated changes in $\beta$-phellandrene emissions for three different years accounting for MPB kill (Fig. 4b, c, e, f) and OB kill (Fig. 4a, d). Although MPB infestation peaked in BC in 2007 and the western US in 2009, the MPB had the largest impact on VOC emissions in BC and the western US in 2004 and 2008, respectively. In later years, the stronger attack effect was overcome by the cumulative mortality of the previous years. In 2004 , emissions of $\beta$-phellandrene decrease locally by up to $10 \%$ due to the mortality effect (Fig. $4 \mathrm{~b}$ ) and increase up to 3 -fold when the attack effect is included (Fig. 4e). In 2008, emissions of $\beta$-phellandrene decrease locally by up to $38 \%$ due to the mortality effect (Fig. 4c) and increase up to fourfold when the attack effect is included (Fig. 4f). In 2002, the OB had the largest impact in both the western US and BC; however, the impact in BC is small (Fig. 4a, d).

Figure 5 shows the impact of all beetles combined in 2002, 2004, and 2008 on the sum of monoterpenes affected in the pine scenario. The impact of bark beetle attack is strongest for $\beta$-phellandrene, therefore, the summed monoterpene emissions have a lower relative increase. However, the absolute increase is larger due to the inclusion of more abundantly emitted monoterpenes (e.g. $\beta$-pinene). With all four monoterpene emissions included, the largest local increase above baseline is $111 \%$ in $2002,70 \%$ in 2004, and $104 \%$ in 2008. The majority of the impact is from the MPB, except in 2002. Although the impact from MPB alone peaks in later years, the impact of all beetles together for the entire region peaks in 2002 due to the large impact of OB in the US in 2002 and because the cumulative mortality is lower in 2002 than in later years (Fig. 5a vs. b, c), causing the attack effect to have a greater impact in 2002.

Figure 6 shows the temporal evolution of simulated total regional emissions of the four monoterpenes affected by beetle attack in BC and the western US. Because the fraction of trees under attack in a year is calculated based on the change in mortality from the current year to the following year, an attack effect cannot be calculated for the final year of mortality in the dataset (2010). In a given year, the more trees under attack, the stronger the attack effect; however, increasing cumulative mortality in later years offsets more of the attack effect. For BC, the maximum increase in total emissions of these four compounds is $7 \%$ above baseline in 2004. For a) 2002 OB Mortality Effect

d) 2002 OB Mortality + Attack Effect

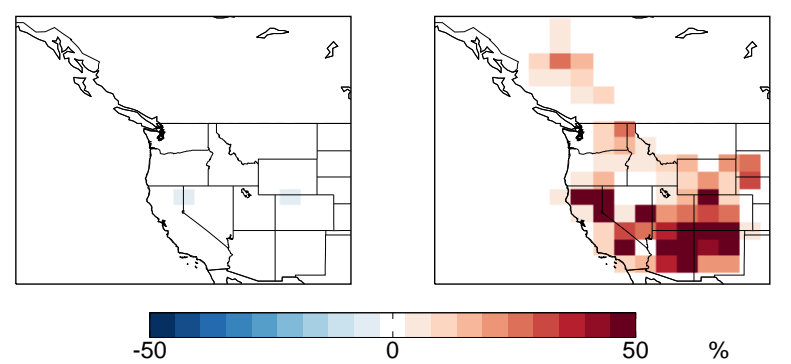

b) 2004 MPB Mortality Effect

e) 2004 MPB Mortality + Attack Effect
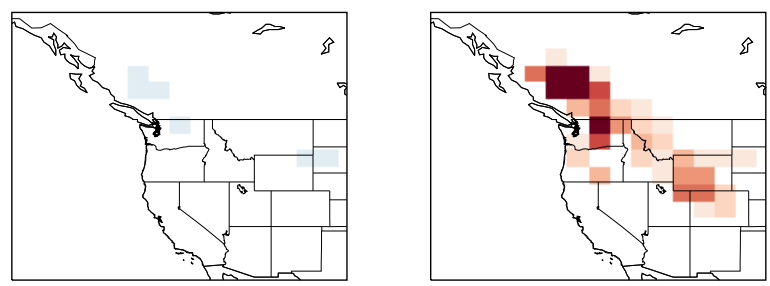

c) 2008 MPB Attack Effect

f) 2008 MPB Mortality + Attack Effect

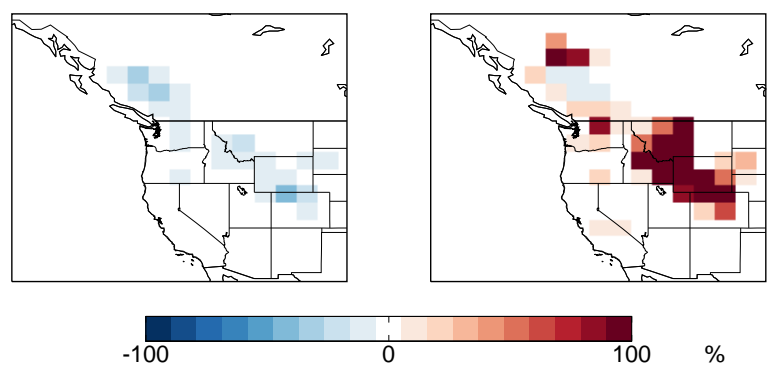

Fig. 4. Change in simulated summer-mean $\beta$-phellandrene emissions due to other beetle attack in 2002 and mountain pine beetle attack in 2004 and 2008 following the pine scenario. Change in emissions due to the mortality effect alone (a-c) and the mortality plus attack effect (d-f). Color bars are saturated at their respected values.

the US, the maximum increase in total emissions of these four compounds is $3 \%$ above baseline in 2008. Although total monoterpene emissions are not significantly perturbed by bark beetle kill, Fig. 5 shows that local effects can be substantially larger. For OB impacts in the US, there is a peak in monoterpene emissions in 2002 associated with the pinyon ips outbreak from 2002-2004 discussed in Sect. 2.1. In other years there is little to no increase in emissions above baseline, and after 2003, emissions return to the baseline level. Overall, OB impacts in BC are small.

\subsection{Impacts on SOA formation in western North America}

Changes in monoterpene emissions throughout western North America impact SOA loading in the region. Figure 7 shows baseline summertime average simulated 
a) 2002 OB Mortality Effect

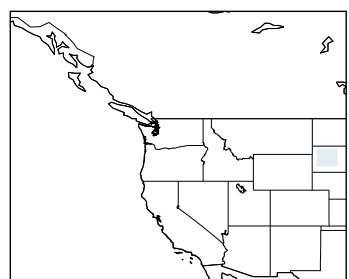

b) 2004 MPB Mortality Effect

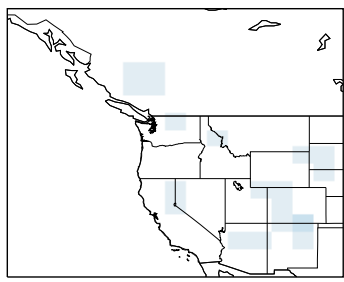

c) 2008 MPB Attack Effect
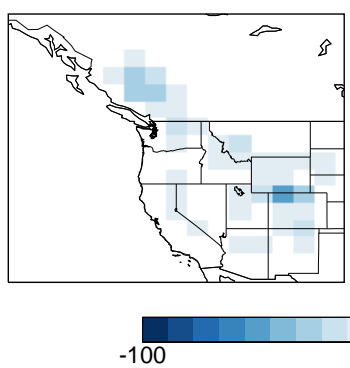

d) 2002 OB Mortality + Attack Effect

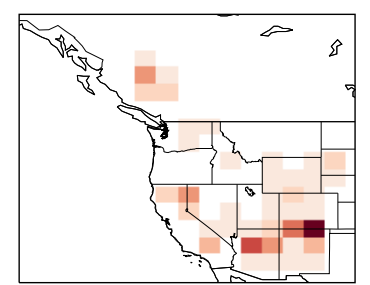

e) 2004 MPB Mortality + Attack Effect

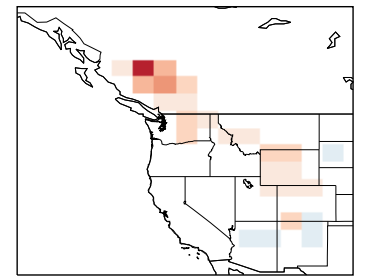

f) 2008 MPB Mortality + Attack Effect

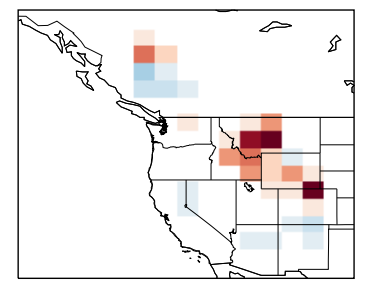

$\%$

Fig. 5. Change in simulated summer-mean emissions of the four monoterpenes impacted by all beetles in 2002, 2004, and 2008. Change in emissions due to the mortality effect alone $(\mathbf{a}-\mathbf{c})$ and the mortality effect plus the attack effect $(\mathbf{d}-\mathbf{f})$. Color bar is saturated at $100 \%$.

concentrations of SOA from each of the six monoterpenes. These SOA distributions largely mimic the spatial patterns of the monoterpene emissions shown in Fig. 3 due to the rapid oxidation and formation of the aerosol products in the model. Both 3-carene and $\beta$-pinene continue to be the dominant SOA precursors for the pine scenario, but $\beta$-phellandrene emissions make a more important relative contribution to SOA than VOC emissions as a result of the high estimated SOA yields for this compound (Table 2). Here we assess the spatial and temporal changes in SOA concentration caused by the changes in the monoterpenes discussed. We show only the integrated effects of all the monoterpene precursors on SOA concentrations in the pine scenario.

The largest overall impact on SOA surface concentration from the attack effect from all beetles (MPB plus OB) for the whole region (western US plus BC) is in the year 2002 (Fig. 8) just as for monoterpenes (Fig. 5). During this year, the mortality effect causes widespread decreases in SOA from $1-5 \%$. Including the attack effect, specific areas see in-

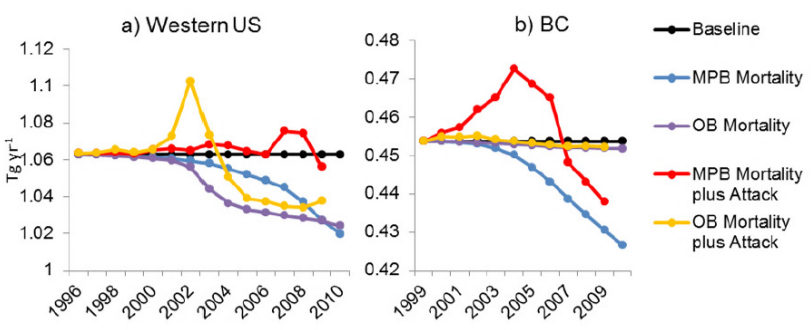

Fig. 6. Time series showing evolution of the simulated total regional monoterpene emissions (sum of 3 -carene, $\beta$-pinene, $\beta$ phellandrene, $\mathrm{p}$-cymene, $\alpha$-pinene, and sabinene) affected by mountain pine beetle (MPB) and other bark beetle (OB)-caused tree mortality in (a) western US and (b) BC.

creases above a baseline of up to $37 \%$ with a widespread increase above a baseline of $\sim 10 \%$. The year with the smallest overall attack effect impact is in 2009 , likely a combination of decreasing infestation of MPB in BC and a decreasing infestation of the OB in the western US, allowing the mortality effect to overcome the attack effect in this year. Figure 8 also includes the impact of MPB and OB attack on SOA in 2004 and 2008.

\subsection{Alternate spruce scenario}

The impact of bark beetle infestation on observed monoterpene emissions differs considerably in an Engelmann spruce vs. a lodgepole pine, both in magnitude and in speciation (with two additional monoterpenes $\alpha$-pinene and sabinene affected) (Table 1). Results in Sects. 3.1 and 3.2 assumed that emissions from all needleleaf trees respond the same as the lodgepole pine; we show here the impact of instead assuming a spruce-like response.

In this scenario, the maximum increases in monoterpene emissions (3-fold) and SOA (over 2-fold) caused by mountain pine beetle occurs in 2008 (Fig. 9). The mortality effect is the same for both the pine and spruce scenarios, whereas the attack effect, which takes into account the different scaleup factors, is much larger for the spruce scenario (3-4 times the impact seen when employing the pine scenario).

This scenario is presented to exemplify a possible range in response. However, evidence suggests that lodgepole pine stands ( $25 \%$ of coverage of BC forests prior to bark beetle infestation) have been preferentially impacted by beetle attack, with little change in Engelmann spruce coverage (Westfall and Ebata, 2011). Thus, the pine scenario results presented in Sects. 3.1 and 3.2 are more likely regionally represented, with possible localized spruce-like response.

\subsection{Implications of bark beetle impacts on SOA}

We compare simulated SOA to measurements of organic aerosol (OA) from the Interagency Monitoring of Protected Visual Environments (IMPROVE) network to provide some 
a) SOA from 3-carene

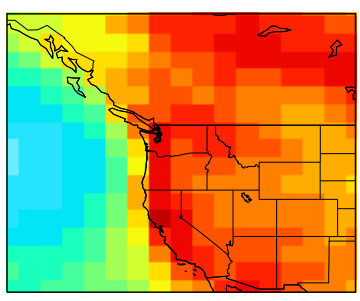

b) SOA from $\beta$-phellandrene

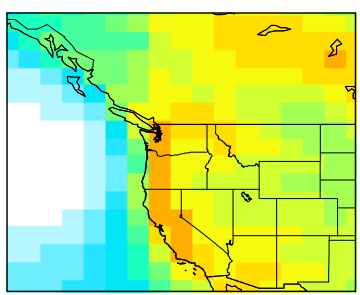

c) SOA from $\alpha$-pinene

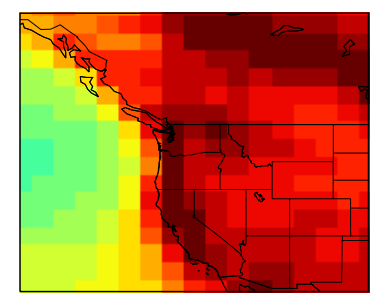

0.001 d) SOA from $\beta$-pinene

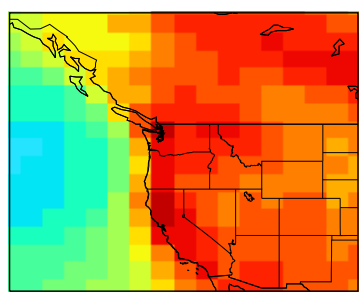

e) SOA from P-cymene

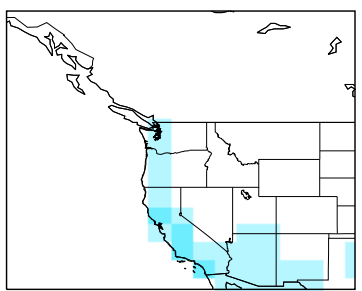

f) SOA from Sabinene

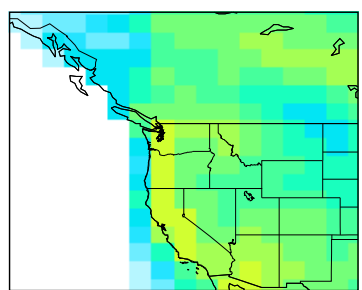

$0.100 \quad 1.000$

$\mu \mathrm{gm}^{-3}$

Fig. 7. Baseline summer-mean simulated concentrations of SOA from (a) 3-carene, (b) $\beta$-phellandrene, (c) $\alpha$-pinene, (d) $\beta$-pinene, (e) $\mathrm{p}$-cymene, and (f) sabinene. Color bar is saturated at $1 \mu \mathrm{g} \mathrm{m}^{-3}$.

context for the simulated aerosol concentration changes due to beetle kill. The IMPROVE network consists of about 200 sites across the US where filters are collected every three days and analyzed for concentrations of speciated fine particulate matter. Organic aerosol typically makes up 15-70\% of total fine particulate matter $\left(\mathrm{PM}_{2.5}\right)$ measured in summertime in the western US. Simulated SOA makes up only a fraction of total simulated OA in the western United States, typically $15-50 \%$ in winter and $40-90 \%$ in summer, with large primary emissions due to wildfires. The model simulation underestimates total observed OA over the region, consistent with previous model studies around the world (e.g. Heald et al., 2005; Volkamer et al., 2006; Lamarque et al., 2012). The factor of 1.4 used in the conversion of OC to OA in the IMPROVE database may also be too low for many areas of the western US (El-Zanan et al., 2005), further widening the gap between observed and simulated OA. However, reconciling this OA measurement-model gap is not the objective of this work.

a) 2002 Mortality Effect

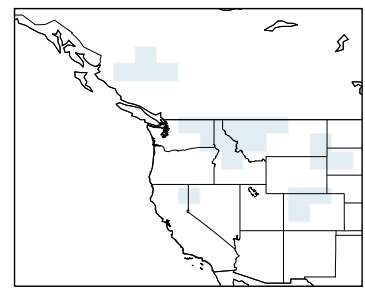

b) 2004 Mortality Effect

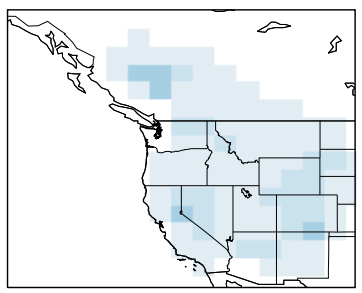

c) 2008 Attack Effect

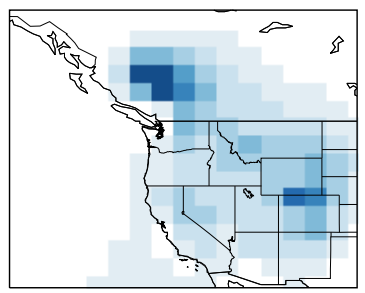

d) 2002 Mortality + Attack Effect

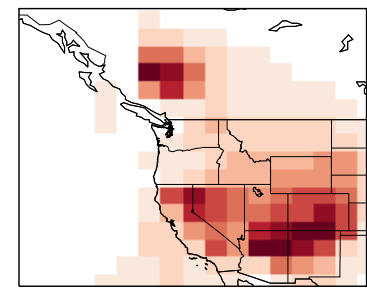

e) 2004 Mortality + Attack Effect

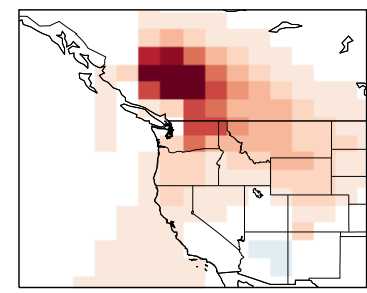

f) 2008 Mortality + Attack Effect

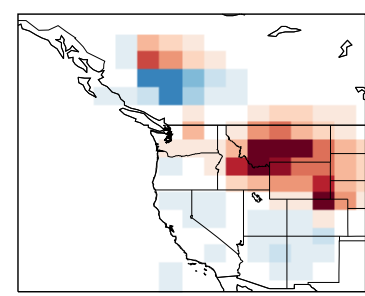

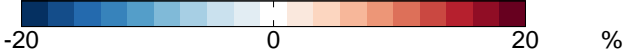

Fig. 8. Change in simulated summer-mean SOA concentration from all six monoterpenes due to the impact of both mountain pine beetle and other beetle attack in 2002, 2004, and 2008 (in the pine scenario). Change due to the mortality effect alone (a-c) and mortality effect plus the attack effect (d-f). The color bar is saturated at $20 \%$.

Figure 10 shows monthly mean measurements from two sites in Montana and Colorado in 2008 that have been impacted by beetle infestation along with baseline and beetleattack simulated SOA concentrations (for both the pine and spruce scenario) and simulated OA concentrations sampled to site location. These sites are examples of areas that saw some of the highest increases in total SOA concentrations above baseline in the western US in our simulation. However, the simulated increase in SOA under the pine scenario (maximum increase of $0.2 \mu \mathrm{g} \mathrm{m}^{-3}$ ) is dwarfed by the seasonal and interannual variability in observed OA which is largely driven by wildfire activity (Spracklen et al., 2007). This suggests that the impacts from beetle infestation may be difficult to detect in surface OA or $\mathrm{PM}_{2.5}$ measurements. However, the spruce scenario results in much larger increases in SOA concentrations due to beetle attack, in this case more than a doubling of SOA concentration in summertime (increases of more than $1 \mu \mathrm{g} \mathrm{m}^{-3}$ ). Although, these changes are 
a) Mortality Effect on Monoterpenes

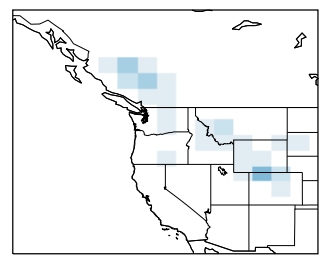

c) Mortality Effect on SOA

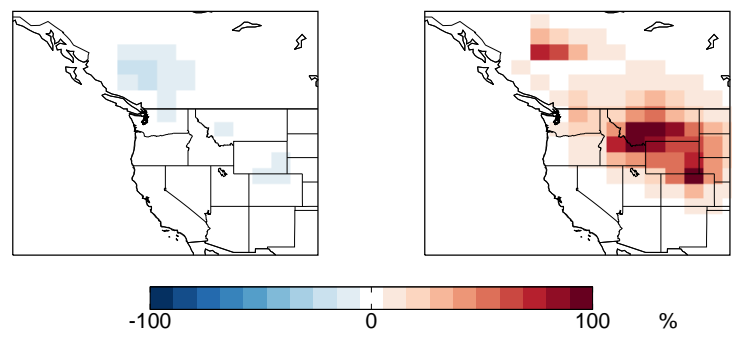

Fig. 9. Change in simulated summer-mean monoterpene emissions and summer-mean SOA concentrations from all four monoterpenes due to the impact of mountain pine beetle attack in 2008 for the spruce scenario (compare with Figs. 5c, 5f, 8c and 8f). (a) Change in monoterpene emissions due to mortality effect alone. (b) Change in monoterpene emissions due to mortality effect plus the attack effect. (c) Change in SOA concentrations due to the mortality effect. (d) Change in SOA concentrations due to the mortality effect plus the attack effect. The color bar is saturated at $100 \%$.

unlikely to lead to significant degradation in air quality, the magnitude of these localized changes may be large enough to observe in surface particulate matter measurements, particularly in areas less affected by wildfires. However, due to uncertainties in simulated SOA concentrations and poor overall model agreement for OA concentrations, it is difficult to make this assessment. Furthermore, the spruce scenario is shown to provide an estimate of uncertainty in the diversity of tree-species response to bark beetle attack, but forests surrounding these particular sites are likely composed of pine species.

Although the changing impact of beetle infestation may be difficult to discern from observations, these biogenic aerosols may be a significant contributor to the natural aerosol background, particularly in light of the EPA's Regional Haze Rule (US EPA, 1999), which mandates a return to "natural visibility conditions" by the year 2064. Changes in SOA concentrations estimated under the spruce scenario $\left(\sim 1 \mu \mathrm{g} \mathrm{m}^{-3}\right)$ are comparable to the natural aerosol levels estimated for the western United States (1.21 $\mathrm{g} \mathrm{m}^{-3}$ US EPA, 2003), suggesting that achieving "natural visibility" may not be possible in forests impacted by beetle infestation.

\section{Uncertainties}

The robustness of changes in emissions following beetle infestation is difficult to ascertain. Here we use monoterpeneincrease data from only one study location (Colorado) for two different tree species (Amin et al., 2012, lodgepole pine data, 2013, Engelmann spruce data). The large differences between the pine and spruce scenarios illustrate the large species-variability in response to beetle attack and the uncertainties that still surround the impact of beetles on atmospheric composition. Duhl et al. (2013) seek to quantify the impacts of MPB on monoterpene emissions from lodgepole pine as well as changes over time; however, their results for a limited number of trees are inconclusive and appear to be dominated by tree-to-tree variability. Beetle attack generally occurs during the summer months when monoterpene emissions are highest (e.g. Tishmack et al., 2005; Safranyik and Carroll, 2006); therefore, we focused on summetime impacts in this study. Although we have assumed that trees are impacted by beetle attack for a full year, it is possible that trees that survive a beetle attack may have an emissions scale-up effect lasting several years, while other trees that succumb quickly to the beetle may only have a scale-up effect lasting a few months. Observational studies done over longer periods of time are required to discern the temporal changes in emissions from a tree under attack. There is also a clear need to study the quantitative change in monoterpene emissions due to other beetles and insect infestations in other tree species (MPB attacking lodgepole pine is by far the most studied combination).

Increased surface temperatures measured in beetle-killed forests by Hais and Kucera (2008) and modeled by Wiedinmyer et al. (2012) may also increase VOC emissions beyond what we show here, as VOC emissions increase exponentially with increasing temperature (Guenther et al., 1993). Simlarly, post-outbreak forestry activity such as salvage logging could impact VOC emissions (e.g. Räisänen et al. 2008).

Following a beetle infestation, there may also be changes in the VOC emissions profile of forests due to recovery that includes establishment and dominance of different tree species. Although postdisturbance vegetation dynamics are not fully understood, Collins et al. (2011) find that in remote forest in Colorado, lodgepole pine stands can be replaced with deciduous trees such as aspen, which emit mainly isoprene. However, in other areas, coniferous trees such as subalpine fir or Engelmann spruce may initially replace lodgepole pine (Collins et al., 2011). Any transformation of vegetation will cause a change in the amounts and types of VOCs emitted, as well as subsequent SOA loadings in the region. Changes in species composition following beetle outbreaks will likely impact the longer term emission characteristics of forests in western North America.

SOA yields are loading-dependent (e.g. Presto and Donahue, 2006; Shilling et al., 2008). Typical total OA concentrations in the atmosphere are less than or equal to $5 \mu \mathrm{g} \mathrm{m}^{-3}$ 

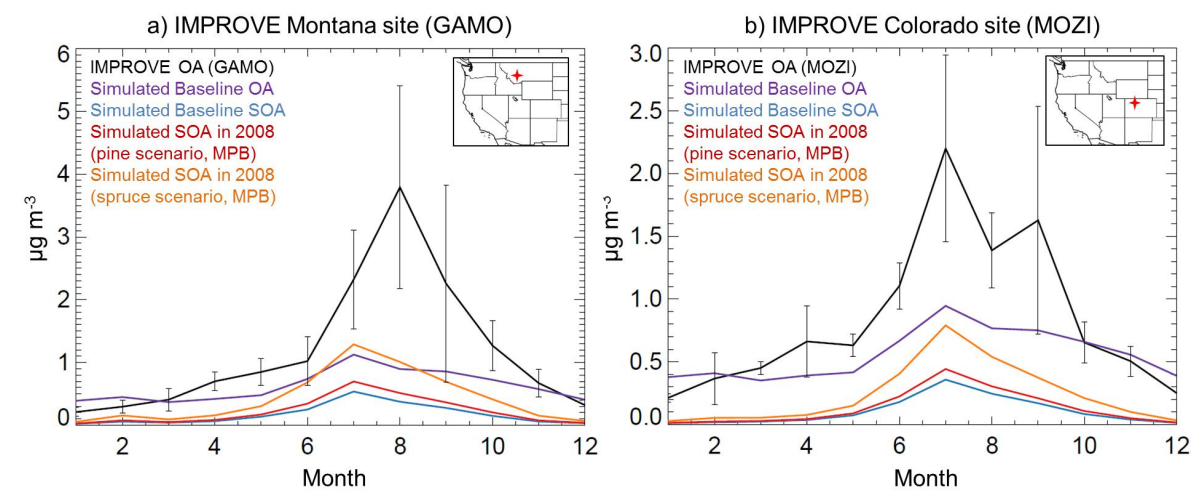

Fig. 10. Comparison between observed baseline IMPROVE OA concentrations from 2008 to simulated baseline OA and SOA at a site in (a) Montana (GAMO) and (b) Colorado (MOZI). Simulated SOA concentrations under the pine and spruce scenario are also shown. Error bars for IMPROVE observations are standard deviation of monthly means.

(Presto and Donahue, 2006). However, most SOA chamber experiments are conducted with much higher organic mass concentrations, including Lee et al. (2006a, b). It is therefore likely that yield parameters used in this study overestimate SOA formation in ambient conditions; however, yield estimates obtained at low loading conditions are not available for all our monoterpene precursors of interest. This overestimate in our simulated SOA is somewhat offset by our neglect of SOA formed via $\mathrm{NO}_{3}$ oxidation and from other precursors (i.e. isoprene, sesquiterpenes, methyl salicylate), emissions of which may also be affected by bark beetle attack. Uncertainties in all these yields preclude any firm estimates of the degree of compensation.

\section{Conclusions}

This is the first modeling study to assess the impact of bark beetle kill on monoterpene emissions and air quality. We show that at least locally, beetle infestation may have a significant impact on atmospheric composition in western North America.

Two main effects emerge from this study - the mortality effect and the attack effect. Spatially, responses to beetle attack can vary greatly with smaller-scale areas showing relatively large changes in monoterpene emissions and SOA concentrations (up to four-fold), while for western North America as a whole, the mortality effect can overcome or greatly mute the attack effect. Any compensation between the mortality and attack effect at the regional scale will depend on the spatial and temporal patterns of tree mortality: compensation will be greater when different areas experience beetle outbreaks in different years. The response to beetle attack also varies from year-to-year, depending on the number of trees under attack and the magnitude of the cumulative mortality effect.
In both the pine and spruce scenario explored here, MPB has the largest impact in BC in 2004 and the western US in 2008, with a much larger impact when the simulated attack effect is based on the response of Engelmann spruce. OB have the largest impact in both BC and the western US in 2002, although the OB impact in BC is small in all years. Although many of the large relative increases in monoterpene emissions and SOA concentrations we see across western North America are not likely observable in measurements of $\mathrm{OA}$ or $\mathrm{PM}_{2.5}$ due to the large annual and interannual variability in these measurements, in areas of spruce under attack and lower OA variability, beetle-induced SOA changes may be observable over time. Furthermore, these changes in natural aerosol, and similar changes resulting from future beetle attacks, may impact the achievement of natural visibility objectives set forth by the US EPA Regional Haze Rule.

This initial modeling study captures the general picture of how beetles may affect monoterpenes and SOA in western North America. MPB outbreaks in western North America are severe and still spreading. Furthermore, other regions in the world also experience large-scale herbivory attacks such as the southeast US (Duehl et al., 2011) and Europe (Seidl et al., 2011). Thus, further experimental work characterizing the effect of herbivory on BVOC emissions is needed. Further work is also required to couple the aerosol impacts examined here to beetle-associated changes in meteorology, ozone and fire susceptibility to attain a complete picture of beetle infestation impacts on air quality.

Acknowledgements. This work was supported by NSF (ATM0929282). AHG and KEH were supported by NSF (ATM-0939021; ATM-0938940). AJHM and JAH were supported by NSF, NOAA and the USDA Forest Service. The CESM project is supported by the National Science Foundation and the Office of Science (BER) of the US Department of Energy. Computing resources were provided by the Climate Simulation Laboratory at NCAR's Computational and Information Systems Laboratory (CISL), spon- 
sored by the National Science Foundation and other agencies. Any opinions, findings, and conclusions or recommendations expressed in this material are those of the author(s) and do not necessarily reflect the views of the National Science Foundation. We thank Louisa Emmons for assistance with the CAM-Chem model and Christine Wiedinmyer, Delphine Farmer, and Jeffrey Collett, Jr. for useful discussion.

Edited by: A. Laaksonen

\section{References}

Amin, H. S., Atkins, P. T., Russo, R. S., Brown, A. W., Sive, B. S., Hallar, A. G., and Huff Hartz, K. E.: Effect of bark beetle infestation on secondary organic aerosol precursor emissions, Environ. Sci. Technol., 46, 5696-5703, doi:10.1021/es204205m, 2012.

Amin, H. S., Russo, R. S., Sive, B. S., Hoebeke, E. R., Dodson, C., McCubbin, I. B., Hallar, A. G., and Huff Hartz, K. E.: Monoterpene emissions from bark beetle infested Engelmann spruce trees, Atmos. Environ., doi:10.1016/j.atmosenv.2013.02.025, in press, 2013.

Atkinson, R.: Gas-phase tropospheric chemistry of volatile organic compounds: 1. Alkanes and alkenes, J. Phys. Chem. Ref. Data, 26, 215-290, doi:10.1063/1.556012, 1997.

Bentz, B. J., Regniere, J., Fettig, C. J., Hansen, E. M., Hayes, J. L., Hicke, J. A., Kelsey, R. G., Negron, J. F., and Seybold, S. J.: Climate change and bark beetles of the Western United States and Canada: direct and indirect effects, BioScience, 60, 602-613, doi:10.1525/bio.2010.60.8.6, 2010.

Blande, J. D., Tiiva, P., Oksanen, E., and Holopainen, J. K.: Emission of herbivore-induced volatile terpenoids from two hybrid aspen (Populus tremula $\mathrm{x}$ tremuloides) clones under ambient and elevated ozone concentrations in the field, Glob. Change Biol., 13, 2538-2550, doi:10.1111/j.1365-2486.2007.01453.x, 2007.

Boon, S.: Snow accumulation and ablation in a beetle-killed pine stand in northern interior British Columbia, BC Journal of Ecosystems and Management, 8, 1-13, 2007.

Brilli, F., Cicciloi, P., Frattoni, M., Prestininzi, M., Spanedda, A. F., and Loreto, F.: Constitutive and herbivore-induced monoterpenes emitted by Populus $\mathrm{x}$ euroamericana leaves are key volatiles that orient Chyrsomela populi beetles, Plant Cell Environ., 32, 542552, doi:10.1111/j.1365-3040.2009.01948.x, 2009.

Carroll, A., Taylor, S., Regniere, J., and Safranyik, L.: Effect of climate change on range expansion by the mountain pine beetle in British Columbia, in: Mountain Pine Beetle Symposium: Challenges and Solutions, Natural Resources Canada, Canadian Forest Service, Pacific Forestry Centre, Victoria, British Columbia, 223-232, 2003.

Collins, B. J., Rhoades, C. C., Hubbard, R. M., and Battaglia, M. A.: Tree regeneration and future stand development after bark beetle infestation and harvesting in Colorado lodgepole pine stands, Forest Ecol. Manage., 261, 2168-2175, doi:10.1016/j.foreco.2011.03.016, 2011.

Duehl, A. J., Koch, F. H., and Hain, F. P.: Southern pine beetle regional outbreaks modeled on landscape, climate and infestation history, Forest Ecol. Manag., 261, 473-479, doi:10.1016/j.foreco.2010.10.032, 2011.

Duhl, T. R., Gochis, D., Guenther, A., Ferrenberg, S., and Pendall, E.: Emissions of BVOC from lodgepole pine in response to mountain pine beetle attack in high and low mortality forest stands, Biogeosciences, 10, 483-499, doi:10.5194/bg-10-4832013, 2013.

Edburg, S. L., Hicke, J. A., Brooks, P. D., Pendall, E. G., Ewers, B. E., Norton, U., Gochis, D., Gutmann, E. D., and Meddens, A. J. H.: Cascading impacts of bark beetle-caused tree mortality on coupled biogeophysical and biogeochemical processes, Front. Ecol. Environ., 10, 416-424, doi:10.1890/110173, 2012.

El-Zanan, H. S., Lowenthal, D. H., Zielinska, B., Chow, J. C., and Kumar, N.: Determination of the organic aerosol mass to organic carbon ratio in IMPROVE samples, Chemosphere, 60, 485-496, doi:10.1016/j.chemosphere.2005.01.005, 2005.

Fry, J. L., Kiendler-Scharr, A., Rollins, A. W., Wooldridge, P. J., Brown, S. S., Fuchs, H., Dubé, W., Mensah, A., dal Maso, M., Tillmann, R., Dorn, H.-P., Brauers, T., and Cohen, R. C.: Organic nitrate and secondary organic aerosol yield from $\mathrm{NO}_{3}$ oxidation of $\beta$-pinene evaluated using a gas-phase kinetics/aerosol partitioning model, Atmos. Chem. Phys., 9, 14311449, doi:10.5194/acp-9-1431-2009, 2009.

Fry, J. L., Kiendler-Scharr, A., Rollins, A. W., Brauers, T., Brown, S. S., Dorn, H.-P., Dubé, W. P., Fuchs, H., Mensah, A., Rohrer, F., Tillmann, R., Wahner, A., Wooldridge, P. J., and Cohen, R. C.: SOA from limonene: role of $\mathrm{NO}_{3}$ in its generation and degradation, Atmos. Chem. Phys., 11, 3879-3894, doi:10.5194/acp-113879-2011, 2011.

Gara, R. I., Littke, W. R., and Rhoades, D. F.: Emission of ethanol and monoterpenes by fungal infected lodgepole pine trees, Phytochemistry, 34, 987-990, doi:10.1016/S0031-9422(00)90699X, 1993.

Gent, P. R., Danabasoglu, G., Donner, L. J., Holland, M. M., Hunke, E. C., Jayne, S. R., Lawrence, D. M., Neale, R. B., Rasch, P. J., Vertenstein, M., Worley, P. H., Yang, Z.-L., and Zhang, M.: The community climate system model version 4, J. Climate, 24, 4973-4991, doi:10.1175/2011JCLI4083.1, 2011.

Griffin, R., Cocker, D., Flagan, R., and Seinfeld, J.: Organic aerosol formation from the oxidation of biogenic hydrocarbons, J. Geophys. Res., 104, 3555-3567, doi:10.1029/1998JD100049, 1999.

Guenther, A. B., Zimmerman, P. R., and Harley, P. C.: Isoprene and monoterpene emission rate variability: model evaluations and sensitivity analyses, J. Geophys. Res., 98, 12609-12617, doi:10.1029/93JD00527, 1993.

Guenther, A. B., Jiang, X., Heald, C. L., Sakulyanontvittaya, T., Duhl, T., Emmons, L. K., and Wang, X.: The Model of Emissions of Gases and Aerosols from Nature version 2.1 (MEGAN2.1): an extended and updated framework for modeling biogenic emissions, Geosci. Model Dev., 5, 1471-1492, doi:10.5194/gmd-51471-2012, 2012.

Hais, M. and Kucera, T.: Surface temperature change of spruce forest as a result of bark beetle attack: Remote sensing and GIS approach, Eur. J. For. Res., 127, 327-336, doi:10.1007/s10342008-0208-8, 2008.

Hao, L. Q., Romakkaniemi, S., Yli-Pirilä, P., Joutsensaari, J., Kortelainen, A., Kroll, J. H., Miettinen, P., Vaattovaara, P., Tiitta, P., Jaatinen, A., Kajos, M. K., Holopainen, J. K., Heijari, J., Rinne, J., Kulmala, M., Worsnop, D. R., Smith, J. N., and Laaksonen, A.: Mass yields of secondary organic aerosols from the oxidation of a-pinene and real plant emissions, Atmos. Chem. Phys., 11, 1367-1378, doi:10.5194/acp-11-1367-2011, 2011. 
Heald, C. L., Jacob, D. J., Park, R. J., Russell, L. M., Huebert, B. J., Seinfeld, J. H., Liao, H., and Weber, R. J.: A large organic aerosol source in the free troposphere missing from current models, Geophys. Res. Lett., 32, L18809, doi:10.1029/2005GL023831, 2005.

Heald, C. L., Henze, D. K., Horowitz, L. W., Feddema, J., Lamarque, J.-F., Guenther, A., Hess, P. G., Vitt, F., Seinfeld, J. H., Goldstein, A. H., and Fung, L.: Predicted change in global secondary organic aerosol concentrations in response to future climate, emissions, and land use change, J. Geophys. Res., 113, D05211, doi:10.1029/2007JD009092, 2008.

Heijari, J., Blande, J. D., and Holopainen, J. K.: Feeding of large pine weevil on Scots pine stem triggers localised bark and systemic shoot emission of volatile organic compounds, Environ. Exp. Bot., 71, 390-398, doi:10.1016/j.envexpbot.2011.02.008, 2011.

Hicke, J. A., Logan, J. A., Powell, J., and Ojima, D. S.: Changing temperatures influence suitability for modeled mountain pine beetle (Dendroctonus ponderosae) outbreaks in the Western United States, J. Geophys. Res., 111, G02019, doi:10.1029/2005JG000101, 2006.

Hicke, J. A., Allen, C. D., Desai, A. R., Dietze, M. C., Hall, R. J., Ted Hogg, E. H., Kashian, D. M., Moore, D., Raffa, K. F., Sturrock, R. N., and Vogelmann, J.: Effects of biotic disturbances on forest carbon cycling in the United States and Canada, Glob. Change Biol., 18, 7-34, doi:10.1111/j.1365-2486.2011.02543.x, 2012a.

Hicke, J. A., Johnson, M. C., Hayes, J. L., and Preisler, H. K.: Effects of bark beetle-caused tree mortality on wildfire, For. Ecol. Manage., 271, 81-90, doi:10.1016/j.foreco.2012.02.005, 2012b.

Jones, M. E., Paine, T. D., Fenn, M. E., and Poth, M. A.: Influence of ozone and nitrogen deposition on bark beetle activity and nitrogen deposition on bark beetle activity under drought conditions, Forest Ecol. Manag., 200, 67-76, doi:10.1016/j.foreco.2004.06.003, 2004.

Jost, R., Rice, A., Langor, D., and Boluk, Y.: Monoterpene emissions from lodgepole and Jack pine bark inoculated with mountain pine beetle-associated fungi, J. Wood Chem. Technol., 28, 37-46, doi:10.1080/02773810801916407, 2008.

Kurz, W. A., Stinson, G., Rampley, G. J., Dymond, C. C., and Neilson, E. T.: Risk of natural disturbances makes future contribution of Canada's forests to the global carbon cycle highly uncertain, P. Natl. Acad. Sci. USA, 105, 1551-1555, doi:10.1073/pnas.0708133105, 2008.

Lawrence, D., Oleson, K. W., Flanner, M. G., Thornton, P. E., Swenson, S. C., Lawrence, P. J., Zeng, X., Yang, Z.-L., Levis, S., Skaguchi, K., Bonan, G. B., and Slater, A. G.: Parameterization improvements and functional and structural advances in version 4 of the community land model, Journal of Advances in Modeling Earth Systems, 3, 1942-2466, doi:10.1029/2011MS000045, 2011.

Lamarque, J.-F., Emmons, L. K., Hess, P. G., Kinnison, D. E., Tilmes, S., Vitt, F., Heald, C. L., Holland, E. A., Lauritzen, P. H., Neu, J., Orlando, J. J., Rasch, P. J., and Tyndall, G. K.: CAM-chem: description and evaluation of interactive atmospheric chemistry in the Community Earth System Model, Geosci. Model Dev., 5, 369-411, doi:10.5194/gmd-5-369-2012, 2012.

Lawrence, P. J. and Chase, T. N.: Representing a new MODIS consistent land surface in the Community Land Model (CLM 3.0), J.
Geophys. Res., 112, G01023, doi:10.1029/2006JG000168, 2007. Lee, A., Goldstein, A. H., Keywood, M. D., Gao, S., Varutbangkul, V., Bahreini, R., Ng, N. L., Flagan, R. C., and Seinfeld, J. H.: Gas-phase products and secondary organic aerosol yields from the ozonolysis of ten different terpenes, J. Geophys. Res., 111, D07302, doi:10.1029/2005JD006437, 2006a.

Lee, A., Goldstein, A. H., Kroll, J. H., Ng, N. L., Varutbangkul, V., Flagan, R. C., and Seinfeld, J. H.: Gas-phase products and secondary aerosol yields from the photooxidation of 16 different terpenes, J. Geophys. Res., 111, D17305, doi:10.1029/2006JD007050, 2006b.

Litvak, M. E. and Monson, R. K.: Patterns of induced and constitutive monoterpene production in conifer needles in relation to insect herbivory, Oecologia, 114, 531-540, doi:10.1007/s004420050477, 1998.

Logan, J. A. and Powell, J. A.: Ghost forests, global warming, and the mountain pine beetle (Coleoptera: Scolytidae), American Entomologist, 47, 160-173, 2001.

Lohmann, U. and Feichter, J.: Global indirect aerosol effects: a review, Atmos. Chem. Phys., 5, 715-737, doi:10.5194/acp-5-7152005, 2005.

Man, G.: Major Forest Insect and Disease Conditions in the United States: 2010 Update, United States Department of Agriculture Forest Health Protection Publications, Washington, DC, 2012.

Meddens, A. J. H., Hicke, J. A., and Ferguson, C. A.: Spatial and temporal patterns of observed bark beetle-caused tree mortality in British Columbia and the Western US, Ecol. Appl., 22, 18761891, doi:10.1890/11-1785.1, 2012.

Mentel, Th. F., Wildt, J., Kiendler-Scharr, A., Kleist, E., Tillmann, R., Dal Maso, M., Fisseha, R., Hohaus, Th., Spahn, H., Uerlings, R., Wegener, R., Griffiths, P. T., Dinar, E., Rudich, Y., and Wahner, A.: Photochemical production of aerosols from real plant emissions, Atmos. Chem. Phys., 9, 4387-4406, doi:10.5194/acp9-4387-2009, 2009.

Odum, J. R., Jungkamp, T. P. W., Griffin, R. J., Forstner, H. J. L., Flagan, R. C., and Seinfeld, J. H.: Aromatics, reformulated gasoline, and atmospheric organic aerosol formation, Environ. Sci. Technol., 31, 1890-1897, doi:10.1021/es9605351, 1997.

Pare, P. W. and Tumlinson, J. H.: Plant volatiles as a defense against insect herbivores, Plant Physiol., 121, 325-331, doi:10.1104/pp.121.2.325, 1999.

Perrot, D., Molotch, N. P., Musselman, K. N., and Pugh, E. T.: Modeling the effects of the mountain pine beetle on snowmelt in a subalpine forest, Ecohydrology, doi:10.1002/eco.1329, 2012.

Pfeifer, E. M., Hicke, J. A., and Meddens, A. J. H.: Observations and modeling of aboveground tree carbon stocks and fluxes following a bark beetle outbreak in the Western United States, Glob. Change Biol., 17, 339-350, doi:10.1111/j.13652486.2010.02226.x, 2010.

Presto, A. A. and Donahue, N. M.: Investigation of $\alpha$-pinene + ozone secondary organic aerosol formation at low total aerosol mass, Environ. Sci. Technol., 40, 3536-3543, doi:10.1021/es052203z, 2006.

Prieme, A., Torben, B. K., Glasius, M., and Christensen, S.: Herbivory by the weevil, Strophosoma melanogrammum, causes severalfold increase in emission of monoterpenes from young Norway spruce (Picea abies), Atmos. Environ., 34, 711-718, doi:10.1016/S1352-2310(99)00357-X, 2000. 
Raffa, K. F., Aukema, B. H., Bentz, B. J., Carroll, A. L., Hicke, J. A., Turner, M. G., and Romme, W. H.: Cross-scale drivers of natural disturbances prone to anthropogenic amplification: the dynamics of bark beetle eruptions, BioScience, 58, 501-517, doi:10.1641/B580607, 2008.

Räisänen, T., Ryyppö, A., and Kellomäki, S.: Impact of timber feeling on the ambient monoterpene concentration of a Scots pine (Pinus sylvestris L.) forest, Atmos. Environ., 42, 6759-6766, 2008.

Ramankutty, N., Evan, A. T., Monfreda, C., and Foley, J. A.: Farming the planet: 1. Geographic distribution of global agricultural lands in the year 2000, Global Biogeochem. Cy., 22, GB1003, doi:10.1029/2007GB002952, 2008.

Rienecker, M. M., Suarez, M. J., Todling, R., Bacmeister, J., Takacs, L., Liu, H.-C., Gu, W., Sienkiewicz, M., Koster, R. D., Gelaro, R., Stagner, I., and Nielsen, J. E.: The GEOS-5 data assimilation system - documentation of versions 5.0.1, 5.1.0, and 5.2.0, Technical Report Series on Global Modeling and Data Assimilation, 27, 97 pp., 2008.

Safranyik, L. and Carroll, A. L.: The mountain pine beetle: a synthesis of biology, management, and impacts in lodgepole pine, edited by: Safranyik, L. and Wilson, B., Natural Resouces Canada, Canadian Forest Service, Victoria, British Columbia, 366, 2006.

Seidl, R., Schelhaas, M. J., and Lexer, M. J.: Unraveling the drivers of intensifying forest disturbance regimes in Europe, Glob. Change Biol., 17, 2842-2852, doi:10.1111/j.13652486.2011.02452.x, 2011.

Shilling, J. E., Chen, Q., King, S. M., Rosenoern, T., Kroll, J. H., Worsnop, D. R., McKinney, K. A., and Martin, S. T.: Particle mass yield in secondary organic aerosol formed by the dark ozonolysis of $\alpha$-pinene, Atmos. Chem. Phys., 8, 2073-2088, doi:10.5194/acp-8-2073-2008, 2008.

Simard, M., Romme, W. H., Griffin, J. M., and Turner, M. G.: Do mountain pine beetle outbreaks change the probability of active crown fire in lodgepole pine forests? Ecol. Monogr., 81, 3-24, doi:10.1890/10-1176.1, 2011.

Spracklen, D. V., Logan, J. A., Mickley, L. J., Park, R. J., Yevich, R., Westerling, A. L., and Jaffe, D. A.: Wildfires drive interannual variability of organic carbon aerosol in the Western US in summer, Geophys. Res. Lett., 34, L16816, doi:10.1029/2007GL030037, 2007.
Surratt, J. D., Gomez-Gonzalez, Y., Chan, A. W. H., Vermeylen, R., Shahgholi, M., Kleindienst, T. E., Edney, E. O., Offenberg, J. H., Lewandowski, M., Jaoui, M., Maenhaut, W., Claeys, M., Flagan, R. C., and Seinfeld, J. H.: Organosulfate formation in biogenic secondary organic aerosol, J. Phys. Chem.-US, 112, 8345-8378, doi:10.1021/jp802310p, 2008.

Staudt, M. and Lhoutellier, L.: Volatile organic compound emission from Holm oak infested by Gypsy moth larvae - evidence for distinct responses in damaged and undamaged leaves, Tree Physiol., 27, 1433-1440, 2007.

Taylor, S. W., Carroll, A. L., Alfaro, R. I., and Safranyik, L.: The mountain pine beetle: a synthesis of biology, management and impacts in lodgepole pine, edited by: Safranyik, L. and Wilson, B., Natural Resources Canada, Canadian Forest Service, Victoria, British Columbia, 67-94, 2006.

Tishmack, J., Mata, S. A., and Schmid, J. M.: Mountain pine beetle emergence from lodgepole pine at different elevations near Fraser, CO, USDA Forest Service, Research Note RMRS-RN27, 2005.

United States Environmental Protection Agency (US EPA): Regional Haze Regulations, Federal Register, Vol. 64, No. 126, 1999.

United States Environmental Protection Agency (US EPA): Guidance for Estimating Natural Visibility Conditions Under the Regional Haze Rule, EPA 454/B-03-005, Office Of Air Quality Planning And Standards, Research Triangle Park, NC, 2003.

Volkamer, R., Jimenez, J. L., San Martini, F., Dzepina, K., Zhang, Q., Salcedo, D., Molina, L. T., Worsnop, D. R., and Molina, M. J.: Secondary organic aerosol formation from anthropogenic air pollution: Rapid and higher than expected, Geophys. Res. Lett., 33, L17811, doi:10.1029/2006GL026899, 2006.

Westfall, J. and Ebata, T.: Summary of Forest Health Conditions in British Columbia, British Columbia Ministry of Forests and Range, Pest Management Report No. 15, Victoria, Canada, 2011.

Wiedinmyer, C., Barlage, M., Tewari, M., and Chen, F.: Meteorological impacts of forest mortality due to insect infestation in Colorado, Earth Interact., 16, 1-11, doi:10.1175/2011EI419.1, 2012.

Winer, A. M., Atkinson, R., and Pitts Jr., J. N.: Gaseous nitrate radical: possible nighttime atmospheric sink for biogenic organic compounds, Science, 224, 156-159, doi:10.1126/science.224.4645.156, 1984. 